\title{
PENDIDIKAN LINGKUNGAN HIDUP PADA JENJANG PENDIDIKAN DASAR
}

\author{
Oleh: Sri Hayati $\left.{ }^{\star}\right)$
}

\begin{abstract}
ABSTRAK
Saat ini kita sedang menyaksikan suatu transisi cakrawala yang tak terbatas ke pencarian keseimbangan dalam ruang yang sempit atau bahkan yang tak terbatas. Pada intinya, dunia berada dalam masa transisi di mana bentuk sosial, tata cara yang berlangsung, serta nilai-nilai akan berlalu sebelum bentukbentuk dan metodologi baru punya waktu yang cukup untuk menggantikannya (Soerjani, 2000: 28-29). Dalam hal ini terjadi interaksi yang rumit, di mana jalinan interaksi lokal tidak lagi dapat dibedakan dengan jalinan interaksi dalam skala global. Dampak dari proses ini adalah beban yang cukup berat bagi sumber daya alam dalam proporsi yang memacu pada ketergantungan dan pertentangan baru yakni eksploitasi sumber daya alam yang tidak terkendali, terjadinya limbah, pencemaran, dan kemiskinan. Permasalahan kerusakan hubungan yang harmonis antara manusia dengan lingkungan, kemudian merebak secara global. Perluasan padang pasir, penggundulan hutan, erosi tanah, hujan asam dan pencemaran udara perkotaan menjadi agenda internasional. Selain itu, ditambah pula dengan berlubangnya lapisan ozon, pemanasan global, dan ancaman terhadap keanekaragaman hayati (World Commission on Environment and Development, 1995)

Makalah ini mengkaji pendidikan lingkungan hidup pada jenjang pendidikan dasar yang difokuskan pada bagaimana konsep-konsep dasar dan permasalahan lingkungan hidup dapat diadopsi oleh siswa pada jenjang pendidikan dasar. Hal ini penting karena: pertama, pendidikan merupakan salah satu proses untuk dapat menjadikan diri seseorang lebih dewasa (Bloom, 1981). Perubahan tingkah laku merupakan indikator dari kedewasaan (Gagne, 1977). Kedua, proses pendewasaan menurut Piaget (1977) berkaitan dengan perkembangan intelektual seseorang dan kesiapan yang dimiliki untuk perkembangan selanjutnya. Siswa sekolah dasar berada pada tahap operasional konkret di mana berpikir logis yang dimiliki didasarkan pada manipulasi fisik dan obyek, sehingga penanaman konsep lingkungan hidup pada jenjang ini merupakan hal yang strategis. Ketiga, menurut Orams (1993) dengan memodifikasi teori Piaget mengemukakan bahwa proses membangun struktur kognitif dapat terwujud melalui adanya informasi, transformasi, dan penggunaan. Interaksi antara individu dengan lingkungan hidup akan terus berlangsung sejalan dengan adanya pemahaman dan persepsi baru mengenai lingkungan tersebut.
\end{abstract}

Kata kunci: Pendidikan lingkungan hidup, Pendidikan Dasar.

*) Dr. Hj. Sri Hayati, M.Pd., adalah dosen Jurusan Pendidikan Geografi FPIPS UPI. 


\section{Pendahuluan}

Saat ini kita sedang menyaksikan suatu transisi cakrawala yang tak terbatas ke pencarian keseimbangan dalam ruang yang sempit atau bahkan yang tak terbatas. Pada intinya, dunia berada dalam masa transisi di mana bentuk sosial, tata cara yang berlangsung, serta nilai-nilai akan berlalu sebelum bentukbentuk dan metodologi baru punya waktu yang cukup untuk menggantikannya (Soerjani, 2000: 28-29). Dalam hal ini terjadi interaksi yang rumit, di mana jalinan interaksi lokal tidak lagi dapat dibedakan dengan jalinan interaksi dalam skala global. Dalam hal ini terjadi interaksi yang rumit, di mana jalinan interaksi lokal tidak lagi dapat dibedakan dengan jalinan interaksi dalam skala global. Hal tersebut berdampak pada munculnya gaya hidup kosmopolitan, munculnya pola konsumsi dan konsumerisme global, menurunnya kedaulatan negara bangsa, tumbuhnya sistem militer global (pasukan multi nasional), pengakuan tentang terjadinya krisis lingkungan dunia, berkembangnya masalah-masalah kesehatan berskala dunia (seperti penyakit AIDS), munculnya lembaga-lembaga politik dunia (seperti PBB), munculnya gerakan-gerakan pilitik global, perluasan konsep hakhak asasi manusia, dan interaksi rumit antar berbagai agama dunia.

Dampak dari proses ini adalah beban yang cukup berat bagi sumber daya alam dalam proporsi yang memacu pada ketergantungan dan pertentangan baru yakni eksploitasi sumber daya alam yang tidak terkendali, terjadinya limbah, pencemaran, dan kemiskinan. Permasalahan kerusakan hubungan yang harmonis antara manusia dengan lingkungan, kemudian merebak secara global. Data menunjukkan bahwa sekitar $29 \%$ lahan bumi mengalami penggurunan antara ringan, sedang, dan parah, sedangkan $6 \%$ lainnya diklasifikasikan sangat parah. Hutan tropis yang mencakup 6\% luas permukaan bumi namun memiliki keanekaragaman hayati tinggi yaitu sekitar $50 \%$ dari jumlah spesies yang ada keadaannya cukup memprihatinkan. Antara 7,6 sampai dengan 10 juta hektar pertahun mengalami kemusnahan dan masih terus berlanjut hingga saat ini. Selain itu, pembakaran bahan bakar fosil melalui tingkat pertumbuhan industri memberikan kontribusi yang besar terhadap akumulasi $\mathrm{CO} 2$ di atmosfer. Akibat dari akumulasi tersebut, suhu permukaan bumi naik antara $1,5-4,5^{\circ} \mathrm{C}$ yang memungkinkan peningkatan permukaan laut antara 25-40 centimeter sebagai konsekuensi dari pencairan es di daerah kutub. Penggunaan nuklir sebagai alternatif energi fosil memberikan dampak terhadap kebocoran reaktor seperti yang terjadi di Chernobyl (World Commission on Environment and Development, 1995).

Hasil studi menunjukkan bahwa penyebab berbagai gangguan yang terjadi di planet bumi berakar dari tabiat dasar manusia sebagai imperialis biologis di mana ia memerlukan makan dan berkembang biak, tanpa peduli keterbatasan sumber daya alam dalam menyediakan kebutuhan hidup bagi diri dan keturunannya (Chiras, 1991:458). Tabiat ini membentuk mental yang berpandangan bahwa manusia diciptakan untuk menguasai alam serta keberadaan alam itu sendiri tidak terbatas. Temuan tersebut diawali oleh preposisi Malthus bahwa pertumbuhan penduduk akan mengikuti deret ukur sedangkan pertumbuhan pangan mengikuti deret hitung (Todaro, 1995: 275-277). Pada suatu saat sumber daya alam tidak dapat lagi mendukung kebutuhan manusia, sehingga akan terjadi kelaparan, kekurangan gizi, wabah penyakit, bencana alam, dan sebagainya yang dapat menyebabkan penderitaan berkepanjangan. Hasil studi 
lainnya, yaitu Meadow et.al. (1972: 130-134) menunjukkan bahwa kualitas lingkungan hidup akan menurun secara drastis sampai pada titik kerusakan, jika pola konsumsi manusia tetap sejalan dengan garis eksponensial.

Komitmen tentang pengelolaan lingkungan seperti yang di ungkapkan melalui deklarasi Stockholm Tahun 1972 yang dilanjutkan dengan deklarasi Rio Tahun 1992 belum dapat menjadi instrumen yang efektif dalam menyelesaikan permasalahan lingkungan yang terjadi. Negara-negara yang tercakup di dalamnya belum dapat melaksanakan sepenuhnya komitmen tersebut. Berbagai kendala menghambat konsistensi pelaksanaan kesepakatan di atas, antara lain masih rendahnya kesadaran tentang pengelolaan lingkungan hidup di samping kebutuhan ekonomi yang mendesak sehingga mengabaikan faktor-faktor lingkungan.

Berbagai permasalahan di atas merupakan tantangan bagi pengembangan pendidikan untuk dapat memberikan kontribusi terhadap pembentukan perilaku yang bertanggung jawab terhadap lingkungan hidup. Hal ini disebabkan, pendidikan merupakan suatu proses pembelajaran yang dilakukan secara integratif untuk membantu peserta didik dalam hal antara lain memahami lingkungan dengan tujuan akhir meningkatkan perlindungan dan sikap bertanggung jawab terhadap lingkungan hidup. Di samping itu, juga merupakan dasar dalam proses pemecahan masalah lingkungan hidup dengan dasar filosofis keseluruhan, kelestarian, peningkatan dan pemeliharaan agar semuanya menjadi lebih baik (Fien et al., 1997).

\section{Potensi Sumberdaya}

\section{a. Potensi Sumber Daya Alam}

Indonesia merupakan negara kepulauan terbesar di dunia terletak di antara $94^{\circ} 05^{\prime} \mathrm{BT}-141^{\circ} 01^{\prime} \mathrm{BT}$ dan $6^{\circ} 08^{\prime} \mathrm{LU}-11^{\circ} 05^{\prime} \mathrm{LS}$. Terdiri dari 17.850 pulau, 7.667 pulau sudah memiliki nama dan 931 pulau berpenghuni penduduk. Luas lautan yang dimiliki sekitar 5,8 juta $\mathrm{km}^{2}$ atau $70 \%$ dari seluruh wilayah, terdiri dari 0,3 juta $\mathrm{km}^{2}$ perairan teritorial, 2,8 juta $\mathrm{km}^{2}$ perairan Nusantara, dan 2,7 juta perairan Zona Ekonomi Eksklusif. Wilayah teritorial Indonesia membentang sepanjang $5.110 \mathrm{~km}$ dari Barat ke Timur dan $1.888 \mathrm{~km}$ dari Utara ke Selatan, serta membentuk garis pantai sepanjang $81.000 \mathrm{~km}$. Luas daratan Indonesia kurang lebih $1.919 .434 \mathrm{~km}^{2}$ mencakup 27 propinsi.

Secara fisiografis, Indonesia berada di wilayah pertemuan lempeng samudera Indo-Australia, Asia-Pasifik, dan darata Asia. Gerakan antarlempeng tektonik tersebut menimbulkan gejala alam berupa gempa, letusan gunung api, dan tsunami yang sering melanda wilayah perairan Indonesia. Selain itu, fenomena tersebut memberikan keindahan tersendiri bagi topografi wilayah yang merupakan pemandangan khas yang sangat menawan.

Selain itu, terdapat 100 sungai yang panjangnya lebih dari $40 \mathrm{~km}$, yaitu 28 di Irian Jaya, 25 buah di Kalimantan, 18 buah di Jawa, dan 12 buah di Sulawesi. Danau-danau yang besar terdapat 51 buah, yaitu 17 buah di Sumatera, 11 buah di Kalimantan, 10 buah di Irian Jaya, 4 buah di Bali, dan 1 buah di Lombok.

Sebagai negara kepulauan yang berada di ekuator, suhu wilayah Indonesia relatif stabil dan tidak ekstrim. Temperatur pada umumnya memiliki amplitudo yang relatif rendah dan memiliki kelembaban yang tinggi, antara $28^{\circ}$ sampai dengan $38^{\circ}$. Iklim kepulauan dipengaruhi oleh letak geografis yang terletak 
antara dua kontinen yaitu Asia dan Australia, keberadaannya di daerah khatulistiwa serta pola angin musim yang bertiup. Sebagian besar kepulauan Indonesia dipengaruhi oleh iklim tropis dengan dua musim, yaitu penghujan dan kemarau.

Hutan tropik yang terdapat di Indonesia merupakan terluas ketiga di dunia serta memiliki keanekaragaman ekosistem yang tinggi, mulai dari hutan hujan dataran tinggi sampai dengan hutan rawa yang terdapat di dataran rendah. Hutan rawa airtawar dan rawa gambut yang luas dapat dijumpai di Kalimantan, Sumatera, dan Irian Jaya. Kalimantan memiliki hutan kerangas terluas di Asia Tenggara, sedangkan Sulamesi memiliki hutan tanah ultrabasa terluas di dunia. Hutan pegunungan bawah dan atas, juga padang rumput alpin terdapat di puncahpuncak gunung tertinggi di Jawa, Irian, dan Sumatera. Luas dan jenis hutan yang terdapat di Indonesia dapat dilihat lebih seksama pada Tabel 1.

Tabel 1. Jenis dan Luas Hutan di Indonesia

\begin{tabular}{|l|c|}
\hline \multicolumn{1}{|c|}{ Jenis Hutan } & $\begin{array}{c}\text { Luas Kawasan } \\
\text { (Hektar) }\end{array}$ \\
\hline 1. Hutan Dataran Rendah $(<1000 \mathrm{~m})$ & 65.442 .400 \\
\hline 2. Hutan hujan Pegunungan Rendah $(1000-2000 \mathrm{~m})$ & 9.983 .900 \\
\hline 3. Hutan Hujan Pegunungan $(>2000 \mathrm{~m})$ & 2.909 .300 \\
\hline 4. Hutan Tanah Ultrabasa & 2.047 .100 \\
\hline 5. Hutan Batuan Kapur & 7.942 .400 \\
\hline 6. Hutan Musim & 17.300 \\
\hline 7. Hutan Savana & 2.669 .900 \\
\hline 8. Hutan Kerangas & 3.747 .400 \\
\hline 9. Hutan Tepi Sungai & 1.148 .300 \\
\hline 10. Hutan Lahan Basah Dataran Rendah & 1.232 .200 \\
\hline 11. Hutan Rawa Gambut & 1.369 .800 \\
\hline 12. Hutan Rawa & 4.690 .300 \\
\hline 13. Hutan pantai & 3.322 .000 \\
\hline 14. Hutan Bakau (Mangrove) & 3.858 .300 \\
\hline 15. Hutan Bambu, Nipah, dan Sagu & 2.100 \\
\hline \multicolumn{1}{|c|}{ J u m I a h } & 119.700 .500 \\
\hline
\end{tabular}

Sumber: RePPProt, dalam Atlas Keanekaragaman Hayati di Indonesia, 1995.

Keanekaragaman tumbuhan yang terdapat pada hutan di Indonesia sangat tinggi. Terdapat 400 spesies merantai atau 70\% dari spesies meranti di dunia, 122 spesies bambu dari 1200 spesies bambu yang tumbuh di muka bumi, dan memiliki jenis pohon palm yang terbesar di dunia. Hutan tropis Indonesia memiliki bunga besar yang langka yaitu Rafflesia yang dapat dijumpai di Kalimantan, Sumatera, dan Jawa. Selain itu, terdapat 5000 spesies bunga anggrek yang merupakan kebangga bangsa Indonesia, diperkirakan setengahnya terdapat di Irian Jaya dan 2000 spesies di Kalimantan.

Hutan tropik Indonesia sekurang-kurangnya memiliki spesies hewan sebanyak satu juta spesies, atau sekitar $13-16 \%$ spesies hewan dunia. Di hutan hujan dataran rendah terdapat 30.000 spesies kumbang, 666 spesies capung, dan 
122 spesies kupu-kupu. Dari lima badak yang tersisa di dunia, dua spesies di antaranya berada di Indonesia. Terdapat satu spesies gajah dari dua spesies gajah dunia, dan sekitar empat spesies hewan ternak liar Asia Tenggara satu di antaranya terdapat di Indonesia. Aneka burung Indonesia antara lain terdapat 13 rangkong patut, di antaranya rangkong kerdil Sulawesi, rangkong Sumba, dan rangkong badak. Endemisme burung di Indonesia sangat tinggi. Selain itu terdapat 75 spesies burung kaka tua, satu di antaranya adalah kakak tua raja yang termahal di dunia. Komodo, biawak terbesar dan tertua di dunia terdapat di pulau Komodo. Sekurang-kurangnya terdapat 500 spesies ikan tawar, d antaranya ikan arwana.Lumba-lumba air tawar atau lebih dikenal dengan nama pesut terdapat di sungai Mahakam Kalimantan Timur.

Terumbu karang merupakan ekosistem yang khas yang terdapat di daerah tropis, tersebar hampir di seluruh pantai dan laut Indonesia terutama di perairan tenang dan dangkal. Luas terumbu karang yang ada kurang lebih $7.500 \mathrm{~km}^{2}$ mencakup hampir semua jenis antara lain fringing reefs, barrier reefs, atol, dan patch reefs. Keunikan karang dan berbagai jenis ikan yang hidup dalam ekosistem terumbu karang menyebabkan daya tarik wilayah terumbu karang untuk diamati dari dekat. Namun demikian, terumbu karang sangat rentan terhadap kontaminasi yang datang dari luar, sehingga keiatan berupa penangkapan ikan, limbah industri dan rumah tangga, serta pariwisata dpat meyebabkan kerusakan. Pada tahun 1996 kondisi terumbu karang diidentifikasikan 39,5\% rusak, 33,5\% kondisi sedang, $21,7 \%$ kondisi baik, dan hanya 5,3\% dalam kondisi sangat baik.

\section{b. Potensi Sumber Daya Manusia}

Penduduk Indonesia berjumlah lebih dari 200 juta jiwa pada tahun 2000 dengan laju pertumbuhan sebesar 1,7\%. Meskipun kepadatan penduduk Indonesia termasuk jarang yaitu 102 orang per- $\mathrm{km}^{2}$, namun penyebarannya tidak merata antara satu pulau dengan pulau lainnya juga antara propinsi yang satu dengan lainnya. Sebanyak $58,87 \%$ penduduk Indonesia mendiami pulau Jawa yang memiliki luas hanya $7 \%$ dari luas wilayah. Dengan jumlah penduduk 114,987 juta maka kepadatan pulau Jawa mencapai 870 orang per- $\mathrm{km}^{2}$. Sementara itu, Irian Jaya dengan luas wilayah $22 \%$ memiliki kepadatan penduduk 5 orang per-km².

Angka harapan hidup pada waktu lahir adalah 61,5 tahun, angka kematian sebesar 68 per-seribu peduduk. Aksesibilitas penduduk terhadap air bersih sebesar $42 \%$, pelayanan kesehatan $43 \%$, dan sanitasi 44\% (HDR, 1993). Angka melek huruf $60,7 \%$, sementara penduduk usia di atas 5 tahun yang tidak bersekolah sebesar $16,46 \%$, masih sekolah $26,85 \%$, dan tidak sekolah lagi $56,69 \%$ (BPS, 1994). Mata pencaharian penduduk Indonesia pada umumnya petani yaitu sekitar 54\%, mata pencaharian lainnya adalah jasa $38 \%$ dan industri 8\%. Pendapatan perkapita penduduk sebesar US\$ 560 (HDR, 1993).

Pemerataan kesempatan memperoleh pendidikan masih menghadapi masalah. Meskipun program Inpres pendidikan telah berhasil meningkatkan angka partisipasi SD, yang berarti telah tercapainya pemerataan kesempatan mengikuti pendidikan SD, namun pada jenjang di atasnya (SLTP dan SM) kesempatan itu belum merata. Hal ini dapat dilihat dari pencapaian APM SLTP yang baru mencapai $54,8 \%$, SM 31,5\%, dan perguruan tinggi 11,6\%. Selain itu, pada jenjang pra-sekolah angka partisipasinya baru mencapai $12,65 \%$. Keadaan seperti 
digambarkan ini menujukkan bahwa pemerataan kesempatan memperoleh pendidikan bagi setiap warga negara Indonesia masih menghadapi masalah.

Permasalahan mutu pendidikan diantaranya dapat diidentifikasi dari indikator-indikatornya, diantaranya adalah hasil belajar. Pada jenjang pendidikan dasar prestasi belajar yang dicapai siswa lebih rendah dibandingkan dengan negara-negara lain. Hasil studi yang dilakukan oleh Moegiadi (1976) dan Suryadi (1989) menunjukkan bahwa kemampuan rata-rata siswa SD untuk pelajaran pokok (Bahasa Indonesia, Matematika, dan IPS) untuk kelas 6 adalah 35,33 dan 37 pada tahun 1976, sedangkan pada tahun 1989 menjadi 27,7, 21,5, dan 24,2 dibandingkan dengan standar penguasaan (50\%). Dalam skala Internasional, seperti yang dilaporkan Bank Dunia (Greanery, 1992) studi yang dilakukan oleh IAEA (International Association for the Evaluation of Educational Achievement) di Asia Timur menunjukkan bahwa keterampilan membaca siswa kelas IV SD berada pada peringkat terendah. Rata-rata skor membaca untuk SD adalah sebagai berikut: (1) Hongkong 75,5, (2) Singapura 74,0, (3) Thailand 65,1, (4) Filipina 52,6, dan (5) Indonesia 51,7. Hasil penelitian lain menunjukkan bahwa anak-anak Indonesia hanya mampu menguasai $30 \%$ materi bacaan. Mereka menemui kesulitan dalam membaca soal-soal berbentuk uraian yang memerlukan penalaran. Kesulitan ini terjadi diperkirakan mereka sangat terbiasa menghafal dan mengerjakan soal-soal pilihan ganda, di samping proses pembelajaran yang tidak mendukung terhadap pengembangan kemampuan penalaran, seperti yang banyak dikritik orang selama ini.

Permasalahan relevansi dapat diidentifikasi dari kesesuaian antara kemampuan yang diperoleh dari sekolah dengan kebutuhan dalam kehidupan atau pekerjaan. Indikator ini dapat ditunjukkan diantaranya oleh data yang dikeluarkan oleh BAPPENAS (1996) yang dikumpulkan sejak tahun 1990. Berdasarkan data itu, pengangguran terbuka lulusan SMU adalah sebesar $25.47 \%$, lulusan diploma sebesar $27.5 \%$, dan sarjana sebesar $36.60 \%$. Pdahal pada periode yang sama pertumbuhan kesempatan kerja cukup tinggi, yakni untuk masing-masing jenjang adalah sebesar $13.4 \%, 14.21 \%$, dan $15.07 \%$. Selain itu, proporsi siswa yang melanjutkan pendidikan ke jenjang perguruan tinggi juga kecil, yakni hanya sekitar 22-24\% saja. Hal ini berarti bahwa antara 73-74\% lulusan SMU tidak melanjutkan.

Permasalahan-permasalahan sebagaimana dipaparkan di atas memberi dampak kepada mutu sumber daya manusia (SDM) Indonesia, karena mutu SDM merupakan salah satu indikator keberhasilan pendidikan. Hasil analisis Human Development Report tahun 2003 menunjukkan Indonesia menduduki urutan ke 108 dari 170 negara.

\section{Pendidikan Lingkungan Pada Jenjang Pendidikan Dasar}

Sebagai makhluk yang memiliki kemampuan untuk menyebar dan mengatur permukaan bumi sesuai dengan keinginannya, manusia memiliki kecenderungan untuk mendominasi bumi baik dilihat dari sudut tata ruang, fungsional maupun struktural. Kerusakan alam yang terjadi pada dasarnya lebih dititikberatkan pada kemampuan manusia untuk melihat dengan jangkauan jauh melampaui batas kepentingan sendiri di samping kemampuan dalam melihat kenyataan yang sebenarnya dalam kehidupan (Soerjani, 1992:19). Kerusakan lingkungan merupakan manifestasi pengembangan dari permasalahan sosial dan lingkungan yang saling terkait. Pengertian yang mendalam mengenai lingkungan 
alam merupakan isu sosial dan ekologis, sehingga krisis lingkungan dapat dikatakan sebagai hasil interaksi dari berbagai keprihatinan global (Van Rensburg, 1994:1). Perilaku manusia dalam berinteraksi dengan lingkungan menjadi perhatian yang serius. Apabila perilaku seseorang ditentukan oleh setting di mana ia tinggal, maka perilaku itu termasuk ke dalam behavior all setting (Fishben dan Ajzen, 1975:351). Pola tersebut dapat membedakan perilaku seseorang dengan orang lain terhadap obyek pada tempat dan waktu tertentu (Krech \&Ballachey, 1988:15). Dengan demikian, perilaku manusia dalam berinteraksi dengan lingkungan merupakan fokus perhatian yang serius.

Atas dasar pemikiran di atas, maka pendidikan pada dalam hal ini seyogianya berkaitan dengan: (1) pemahaman mengenai budaya silang yang berarti mengakui keberadaan lebih dari satu sudut pandang dan belajar melihat dunia dari perspektif yang berbeda, (2) pembelajaran holistik yang membawa berbagai disiplin ke suatu isu lingkungan meliputi berbagai pendekatan dalam pembelajaran, (3) pelibatan potensi masyarakat yang dapat menjalin hubungan yang akrab dan utama antara lingkungan masyarakat dengan sekolah, dan (4) pemahaman mengenai keterkaitan antara konsep-konsep dasar lingkungan hidup dengan permasalahan di sekitarnya. Konsep-konsep dasar lingkungan hidup tersebut adalah: (1) lingkungan bumi yang terdiri dari komponen fisik, (2) materi siklus berkesinambungan dalam tataran ekosistem, (3) daya dukung lingkungan hidup, dan (4) keunikan kapasitas intelektual manusia yang menghasilkan moral dan perilaku lingkungan yang bertanggung jawab (Swan dan Stapp, 1971).

Model pendidikan lingkunan dapat dikembangkan melalui beberapa hal, yaitu: (1) pendekatan studi yang berorientasi lokal dan global secara integratif, (2) fokus terhadap dunia dalam perspektif lingkungan yang menyerap perspektif secara komprehensif, (3) pendidikan sebagai landasan pengembangan perilaku bertanggung jawab terhadap lingkungan, (4) fokus terhadap pendekatan interdisipliner untuk meningkatkan pemahaman terhadap isu-isu utama dalam mengintegrasikan perspektif lingkungan hidup, dan (6) pelaksanaan cooperative learning untuk memahami peningkatan pluralistik dalam masyarakat.

Oleh karena itu, bentuk pendidikan yang terlalu berorientasi kepada penguasaan materi pelajaran, nampaknya kurang mampu mengangkat kualitas pendidikan kita, baik dilihat dari hasil maupun proses belajar. Dilihat dari hasil belajar misalnya, ternyata tingkat penguasaan materi pelajaran kita sangat memprihatinkan, baik dalam skala nasional, regional apalagi skala internasional. Sementara itu, dilihat dari proses belajar ternyata anak didik kita pun masih jauh ketinggalan oleh bangsa-bangsa lain yang dapat dilihat dari kemampuan dan keterampilan mereka dalam memecahkan masalah oleh karena itulah dalam kerangka reformasi pendidikan, perubahan kurikulum dari yang bersifat subject oriented menjadi competency oriented dianggap strategis. Kemampuan penguasaan materi pembelajaran bukanlah sebagai tujuan, akan tetapi hanya sebagai alat untuk mengembangkan kemampuan-kemampuan tertentu yang diharapkan. Hal tersebut didasarkan kepada perubahan paradigma berpikir tentang hakekat dan isi kurikulum, dari apa yang harus dipelajari siswa (what to learn) menjadi bagaimana siswa belajar (how to learn). Paradigma ini mempersiapkan peserta didik untuk memiliki kemampuan intelektual, emosional, spiritual, dan sosial yang bermutu tinggi. Dengan memiliki kompetensi semacam itu, peserta didik diharapkan mampu untuk menghadapi dan mengatasi segala 
macam akibat dari adanya perkembangan dan perubahan yang terjadi dalam lingkungan yang terdekat sampai yang terjauh (lokal, nasional, regional dan internasional).

Pelaksanaan pendidikan lingkungan, pada jenjang SD, muatan kompetensi yang terkait pengembangan kepribadian memperoleh porsi lebih besar dibandingkan dua kategori kompetensi lainnya. pada jenjang pendidikan dasar yang difokuskan pada bagaimana konsep-konsep dasar dan permasalahan lingkungan hidup dapat diadopsi oleh siswa pada jenjang pendidikan dasar. Hal ini penting karena jenjang ini berada pada periode operasional konkret di mana berpikir logis yang dimiliki didasarkan pada manipulasi fisik dan obyek, sehingga penanaman konsep lingkungan hidup pada jenjang ini merupakan hal yang strategis (Piaget dalam Good \& Brophy, 1990). Selain itu, menurut Orams (1993) dengan memodifikasi teori Piaget mengemukakan bahwa proses membangun struktur kognitif dapat terwujud melalui adanya informasi, transformasi, dan penggunaan. Interaksi antara individu dengan lingkungan hidup akan terus berlangsung sejalan dengan adanya pemahaman dan persepsi baru mengenai lingkungan tersebut.

Strategi implementasi pendidikan lingkungan dikembangkan dari yang berorientasi kepada pengembangan pribadi, menuju kepada yang berorientasi pada kehidupan dan alam pekerjaan (rekonstruksi sosial dan teknologi). Pendekatan humanistik dapat diberlakukan pada awal pendidikan dasar, di mana sejumlah kemampuan dasar untuk keperluan pengembangan pribadi seperti kemampuan membaca, menulis, dan berpikir kritis, serta keberanian mengeluarkan ide atau gagasan, dan bekerjasama perlu ditonjolkan. Selanjutnya, pendidikan yang berorientasi pada alam kehidupan dan alam pekerjaan yaitu kurikulum rekonstruksi sosial dan teknologi dipadukan dengan kurikulum subyek akademik dapat digunakan pada pertengahan dan akhir pendidikan dasar. Pembelajaran berpikir ini dikembangkan dengan menekankan pada aktivitas siswa untuk mencari pemahaman akan obyek, menganalisis dan merekonstruksi, sehingga terbentuk pengetahuan baru dalam diri siswa. Pendidikan dalam hal ini bukan hanya dimaksudkan mentransfer atau memberikan informasi, namun lebih bersifat menciptakan lingkungan yang memungkinkan siswa dapat berpikir membentuk pengetahuan. Lebih jauh, pendidikan merupakan salah satu proses untuk dapat menjadikan diri seseorang lebih dewasa (Bloom, 1981) di mana perubahan tingkah laku merupakan indikatornya (Gagne, 1977).

\section{Penutup}

Pendidikan berbasis pada lingkungan hidup merupakan hal strategis yang seyogianya dilaksanakan terutama pada jenjang pendidikan dasar. Bagaimana pun besarnya potensi sumberdaya alam dalam menunjang kehidupan manusia, nampaknya tidak akan dapat termanfaatkan dengan baik dan optimal secara berkelanjutan, jika kita tidak memiliki komitmen dan tanggung jawab terhadap keberlanjutan sumberdaya itu sendiri. Untuk itu komitmen dan tanggung jawab tersebut harus dibentuk sejak dini. Pendidikan lingkungan hidup pada jenjang pendidikan dasar difokuskan pada bagaimana konsep-konsep dasar dan permasalahan lingkungan hidup dapat diadopsi oleh siswa pada jenjang pendidikan dasar. Hal ini disebabkan pertama, pendidikan merupakan salah satu proses untuk dapat menjadikan diri seseorang lebih dewasa Kedua, proses 
pendewasaan berkaitan dengan perkembangan intelektual seseorang dan kesiapan yang dimiliki untuk perkembangan selanjutnya. Siswa sekolah dasar berada pada tahap operasional konkret di mana berpikir logis yang dimiliki didasarkan pada manipulasi fisik dan obyek, sehingga penanaman konsep lingkungan hidup pada jenjang ini merupakan hal yang strategis. Ketiga, proses membangun struktur kognitif dapat terwujud melalui adanya informasi, transformasi, dan penggunaan. Interaksi antara individu dengan lingkungan hidup akan terus berlangsung sejalan dengan adanya pemahaman dan persepsi baru mengenai lingkungan tersebut. Dengan demikian, melalui pendidikan lingkungan hidup yang dikembangkan ini diharapkan dapat terbentuk generasi yang memiliki komitmen dan tanggung jawab dalam pengelolaan sumber daya alam, sehingga kekayaan yang dimiliki dapat dinikmati oleh generasi masa kini juga masa yang akan datang meskipun generasi tersebut belum lahir. Semoga!!

\section{Daftar Pustaka}

Baharudin, Azizan. 1995. Science, Values and The Environment: On The Need for A Coherent and Holistic Worldview. Dalam Azizan HJ Baharuddin (Ed.) Environment and Development: Ethical and Educational Considerations. Kualalumpur: Institut Kajian Dasar.

Blaikie, N.W.H. 1993. "Education and Environmentalism: Ecological World View and Environmentally Responsible Behaviour". Australian Journal of Environmental Education 9. Supplement August.. p. 14.

Bloom, Benyamin S. 1956. Taxonomy of Educational Objective: Book I Cognitive Domain. N.Y.: Longman Inc.

Chiras, Daniel D. 1991. Environmental Science: Action for a Sustainable Future. California: The Benjamin/Cummings Pub. Co. Inc.

Gage, N.L. \& Berliner, D.C. 1984. Educational Psychology. Dallas: Houghton Miffin Co.

Golley, Frank B. 1987. "Deep Ecology from the Perspective of Ecological Science". An Interdisciplinary Journal Dedicated to the Philosophical Aspects of Environmental Problems. p. 45.

Good, Thomas L. \& Brophy, Jere E. 1990. Educational Psychology. N.Y.: Longman.

Hungerford, H.R. \& Volk, Trudi L. 1990. "Changing Leaner Behaviour Through Environmental Education". The Journal of Environmental Education Vol. 21. p. 3.

Kantor Menteri Negara Lingkungan Hidup. 1996. Agenda 21 Indonesia: Strategi Nasional Untuk Pembangunan Berkelanjutan. Jakarta: Kantor Meneg LH.

Krech, David. Crutchfield, Richard S. \& Ballachey, Egerton L. 1988. Individual in Society. N.Y.: McGraw-Hill Co.

Mark Orams. 1994. "Creative Effective Interpretation for Managing Interaction Between Tourist and Wildlife". Australian Journal of Environmental Education 10. pp 21-34.

Soerjani, Mohamad. 1997. Pembangunan dan Lingkungan: Meniti Gagasan dan Pelaksanaan Sustainable Development. Jakarta: IPPL. 1992. "Ekologi Sebagai Dasar Pemahaman Tentang Lingkungan Hidup". Serasi: Warta Kependudukan dan Lingkungan Hidup No. 24. p. 
2000. Kepedulian Masa Depan, alih bahasa. Jakarta IPPL.

Todaro, Michael P. 1995. Pembangunan Ekonomi di Dunia Ketiga. Terjemahan edisi ketiga. Jakarta: Bumi Aksara.

Van Rensburg, Eureta Janse.1994. "Social Transformation in Response to the Environment Crisis: The Role of Education and Research". Australian Journal of Environmental Education Vol 10. P.1-20.

World Commission on Environment and Development. 1995. Hari Depan Kita Bersama. Terjemahan dari Our Common Future. Jakarta: PT. Gramedia. 